\title{
The Korean Tradition of Translation: From the Primeval Period to the Modern Era*
}

\author{
Ji-won Kim \\ Sejong University
}

\begin{abstract}
The Korean people have lived mainly on the Korean peninsula, forming a cultural community using Korean as an inherited, native language. In the early years, Koreans tried to express their own words with Chinese characters; Hanja was used as a method to express Koreans' proper thoughts and feelings even when they had not their own letters. However, speaking in Korean yet writing in Hanja left Koreans with a sense of incongruence of the written and spoken language. The whole writing system of the Korean language was established with the promulgation of Hangeul, the Korean script which was created by King Sejong during the Joseon Dynasty. In the beginning, Hangeul faced heavy opposition by the literate elite who believed Hanja to be the only legitimate writing system. Later rulers too became hostile to Hangeul. Yet due to the growing Korean nationalism in the nineteenth century and the Gab-o Reformists' push, Hangeul was eventually adopted in official documents for the first time in 1894. The translation into Hangeul generally began to flourish in the late nineteenth century. Yet before the great Reform, there were frequently Hangeul-translated versions, a majority of
\end{abstract}

\footnotetext{
* This paper was supported by a research grant from Sejong University in 2007.
} 
42 The Korean Tradition of Translation: From the Primeval Period to the Modern Era

which consisted of religious documents like the Bible. These Korean versions of the Bible contributed a great deal to the translation history of Korea and signaled the end of the discrepant language usage between the Korean spoken language and the Chinese written word.

Keywords: Koreans, Korean language, Idu, Hyangchal, Hyangga, Gukyeol, Yeokgwans, Hangeul, Hunmin Jeong-eum, King Sejong, Eonmun, Eonhae

\section{Origin of the Korean People and Language}

Living on the Korean peninsula and the northern part of Manchuria, the Korean people formed a cultural community using Korean as an official language. Although it is not clear exactly when the Korean people began to live on the peninsula and its bordering regions, it has been speculated on the basis of the existing relics and remains to be around 10000-8000 BCE, from the Neolithic period. ${ }^{1}$ The earliest-known Korean pottery dates to around 8000 BCE. There is no consensus concerning the migration process of the Korean people, but their are supposed to have begun to move from Central Asia, generally known as one of the cradles of civilization, to the lands of Mongolia and Manchuria around the Paleolithic Age. And they probably transferred southward from Manchuria to the peninsula and settled there, learning the new skills of the Neolithic Age. It is speculated that some of them might have crossed the sea to Japan to form a part of the Japanese people.

The Gojoseon (literally 'Old Joseon') ${ }^{2}$ Kingdom was founded in

${ }^{1}$ Generally speaking, the Neolithic period began before 6000 BCE, followed by the Bronze Age around 2500 BCE.

2 This romanized Korean word and subsequent ones are marked according to the official Korean language romanization system in South Korea, the Revised Romanization developed by the National Academy of the Korean Language from 
2333 BCE, eventually stretching from the peninsula to much of Manchuria. By the third century BCE, it disintegrated into many successor states. The Three Kingdoms (Goguryeo, Silla, and Baekje) conquered other successor states of Gojoseon and came to dominate the peninsula. The Three Kingdoms competed with each other both economically and militarily. While Goguryeo and Baekje were more powerful for much of the era, especially since the former defeated massive Chinese invasions, the Silla gradually extended its power across Korea and eventually established the first unified state to cover most of the Korean peninsula by 676 .

The Unified Silla itself fell apart in the late ninth century, collapsing into the turbulent Three Kingdoms (892-936), which culminated with the establishment of the Goryeo Dynasty (9361392). During the Goryeo period, laws were codified, a civil service system was introduced and Buddhism flourished. In 1392, General Yi Seong-gye founded the Joseon Dynasty (1392-1910) after a coup. Between 1592 and 1598, Japan invaded Korea, but was eventually repelled predominantly by the Navy led by Admiral Yi Sun-sin. In the 1620s and 1630s, Joseon suffered invasions by the Manchu Qing Dynasty. From the 1870s, Japan initiated a series of steps that would propel Korea out of China's sphere of influence into its own.

Finally in 1910, Japan annexed and controlled Korea until the surrender to the Allied Forces on August 15, 1945. The defeat of Japan, as well as fundamental changes in global politics and ideology, subsequently led to the division of Korea into two occupation zones with the United States in control of the southern half of the peninsula and the Soviet Union taking over the northern portion. The unresolved tensions of the division surfaced in the Korean war of 1950, which ended any hope of a peaceful reunification for the time being, and helped consolidate the dual

1995 and was released to the public on July 7, 2000, by South Korea's Ministry of

Culture and Tourism in Proclamation No. 2000-8. 
system of separate governments, each claiming to be the legitimate government of all of Korea. In the end, two governments of The Republic of Korea (ROK) and The Democratic People's Republic of Korea (DPRK) have been technically at war, though there have been various movements of reconciliation between the two in recent years.

The Korean language as the official tongue of both North Korea and South Korea is spoken by over 70 million people on the Korean peninsula and a number of small and large islands as well as Jeju Island around the peninsula. It is also one of the two official languages in the Yanbian Korean Autonomous Prefecture in China. Besides, there are a great number of Korean speakers in other foreign countries with large groups settling in Australia, Brazil, Canada, China, Japan, the United States, Post-Soviet states, and the Philippines. In terms of territorial size, Korea is a small country, but it is a huge country considering its large population. The total number of Korean speakers is approximated to be far more than 80 million. In terms of its user population, Korean is thirteenth place among several thousand languages in the world including Chinese, Hindi, Spanish, English, Arabic, Portuguese, Russian, Japanese, German, French, and Malay-Indonesian.

As the Korean language is agglutinative in its morphology and SOV in its syntax, its genealogical classification has been greatly debated. Some linguists place it in the Altaic language family, while others consider it to be a language isolate. Characterized by both a vowel harmony and an agglutinative structure, the Korean language seems to belong to the Ural-Altai languages in company with Japanese to which Korean is syntactically somewhat similar. Although it partly adopts Chinese characters as a medium of its expression, the Korean language has very little in common with Chinese. None the less, Korean language, like the Japanese and Vietnamese languages, was influenced by the Chinese language in the form of Sino-Korean words. In fact, numerous linguistic elements of Chinese characters have strongly permeated the Korean 
language. Yet the Korean language cannot be appropriated into Chinese characters due to the radically different structures of the two languages.

In the cultural history of Korea, a great deal of effort to express Korean language with Chinese characters has been exerted since the period of the Three Kingdoms. Although the method of expression with borrowed Chinese characters has a long history, it has partly contributed to a writing system of purely Korean words. The writing system of the Korean language was established with the introduction of Hangeul, ${ }^{3}$ the Korean script, developed by King Sejong in 1443 during the Joseon Dynasty (1392-1910), and proclaimed three years later, so that there would be a satisfactorily way to write Korean words. The characteristics of Hangeul rely primarily on both its originality and scientific design. Unlike other languages made by alternating an existing writing system, Hangeul was invented entirely independent of any particularly functional system.

Despite of the appearance of Hangeul, Koreans could not expel all at once manifold elements of Hanja from Korean words. Subsequently, they could not help jointly using Hanja as semantic symbols and Hangeul as phonetic symbols. In the beginning of their contact with China, Koreans borrowed only vocabulary, but sooner or later accepted the whole system of Hanja as the Chinese influence increased. On the level of cultural exchange with China, the import of Hanja and its modified representation were already in themselves a translating activity.

\footnotetext{
${ }^{3}$ Literally "great script," this Korean term is usually used in South Korea, while North Koreans prefer to call it Chosŏn'gŭl.
} 


\section{Borrowing of Hanja: From the Primeval Period to the Promulgation of Hangeul}

Chinese writing has been known in Korea for over 2,000 years. It was widely used during the Chinese occupation of northern Korea from $108 \mathrm{BC}$ to $313 \mathrm{AD}$. As the Chinese character, Hanja was used for so long as a proper method of expressing Koreans' thoughts and feelings that it affected their intellectual and cultural lives even after the appearance of Hangeul, their own alphabet system. In the ancient periods of the Korean Three Kingdoms of Goguryeo, Baekje and Silla, which dominated the Korean peninsula and parts of Manchuria for much of the first millennium AD, Hanja already presided over Koreans' literary lives. As history books were written about fourth to sixth centuries in the Three Kingdoms, Hanja was established as the method of writing. From then on to the end of nineteenth century, immediately before the Modernization of Korea, Hanja wielded its power so strongly that it remained an inseparable element of Korean culture.

By the fifth century AD, the Koreans were starting to write in Classical Chinese. The dawn of the Korean culture can be traced back to its ancient origin. The ancient literature recorded foundation myths and diverse legends and histories. Samguk Sagi by Kim Busik (in the twelfth century) and Samguk Yusa by Il Yeon (in the thirteenth century), Dongguk Isang Gukjip by Lee Kyu-bo, and Jewang Ungi by Lee Seung-Hui are noteworthy examples. In these historical documents, there are founding myths of the legendary Dangun in Gojoseon and Jumong in Goguryeo, myths of founders in Silla, and the myth of King Suro in Garak State.

All these ancient documents were recorded in Hanja. A great deal of difficulty was indeed involved in the way Korean people expressed their opinions in Hanja, borrowed foreign letters different to the phonetic system of the Korean oral language. Yet there is no 
doubt that Hanja has enabled the Korean people to produce worthy literature. The volume of classics written by Koreans in Hanja is indeed enormous. The persons of high birth as leaders of Korean society exerted themselves to study Hanja on the dimension of nation so that they could express and record freely their opinions with it.

Since the Korean people spoke in Korean and wrote in Hanja, they suffered from discrepancies between the written and spoken language for quite some time. The elements of Hanja infiltrated Korean language, and so many Chinese characters appeared in the Korean vocabulary. ${ }^{4}$ So the first translation in Korea began as an effort to bridge Chinese pictographs and Korean phonetics. As a result of such efforts, Koreans found out two principles in representing Korean language using Chinese characters. The first was to ignore pictographic meanings and to adopt a phonetic function of Chinese characters. For example, Koreans used Chinese character '古' only as a phonetic symbol '고' ('go') regardless of its meaning 'old'. The second was to ignore phonetic pronunciation and adopt the pictographic meaning of Chinese characters only for purely Korean words. For example, the Silla people used Chinese character '水' to represent '물' ('mul') for water regardless of its pronunciation [su].

These principles were widely applicable even to marking names of persons and places. Koreans borrowed a huge number of Chinese words, gave Korean readings and/or meanings to some of the Chinese characters and also invented about 150 new characters, most of which were rare or primarily used for personal or place names. Such proper nouns were used among the Silla people before King Gyungduk (742-765) of the Unified Silla. The Koreans' effort to express their mother tongue in Hanja included not only simple

\footnotetext{
${ }^{4}$ Native Korean words account for about $35 \%$ of total Korean vocabulary, while about $60 \%$ consists of Sino-Korean words. The remaining $5 \%$ comes from loan words from other languages, $90 \%$ of which are from English $<$ http://en.wikipedia.org/wiki/Korean_language\#_note-0 $>$.
} 
48 The Korean Tradition of Translation: From the Primeval Period to the Modern Era

words but also long sentences.

Such attempts were probably carried out also in Goguryeo and Baekje, but only fragmentary ones of Silla are handed down to the present. The earliest result of their efforts dates from 414 AD. They later devised three different systems for writing Korean with Chinese characters: 'Hyangchal,' 'Gugyeol' and 'Idu.' These systems were similar to those developed in Japan and were likely used as models by the Japanese. Until the appearance of Hangeul, Chinese characters were used by the upper class, and several Chinese-based Korean character systems like Idu letters were used by the populace.

The most important product of their hard work was Idu (literally 'clerical writings'), the first Korean utilizing modified Chinese characters. It was a clever writing system whereby Koreans, who spoke a language much different from the Chinese, would modify Chinese characters to express Korean. The key to the system was to use some Chinese characters for their meaning and others for their pronunciation, ignoring the pictographic meaning. The Idu system combined Chinese characters together with special symbols to indicate Korean verb endings and other grammatical markers, and this was used in official and private documents for many centuries.

Hyangchal (literally 'vernacular letters' or 'local letters') is an archaic writing system of Korea and was used to transcribe the Korean language in Hanja. Under the Hyangchal system, Chinese characters were given a Korean reading based on the syllable associated with the character. The Hyangchal system used Chinese characters to represent all the sounds of Korean and was used chiefly to write poetry. The first uniquely Korean forms of poetry, "Seodongyo" and "Hyeseongga," representatives of Hyangga, were written especially in Hyangchal during the reign of King

\footnotetext{
5 Only twenty five poems of Hyangga survive. The Samguk Yusa contains fourteen poems, and the "Gyunyeojeon", a set of biographies of prominent monks, contains eleven poems.
} 
Jinpyung (579-632) of Silla. ${ }^{6}$

Gugyeol (literally 'phrase parting') is a system for rendering texts written in Classical Chinese into understandable Korean. It was mainly used in the Joseon Dynasty, when readings of the Chinese classics were important for social status. Unlike the Idu and Hyangchal systems which preceded it, Gugyeol used specialized markings in conjunction with Chinese characters to represent Korean morphological markers. Also, the Idu and Hyangchal systems were used primarily to render the Korean language into Hanja; on the other hand, Gugyeol sought to render Chinese texts into Korean with minimal misrepresentation. Thus, in Gugyeol, an original classical text was not modified, and additional markers were simply inserted between phrases.

The term 'Idu' could be generally used in two senses. It referred, in a narrow sense, to the system developed during the Goryeo period, and was first referred to by name in the Jewang Ungi. It might also refer to any writing system of representing Korean phonology through Chinese characters. In this sense, the Idu script which includes 'Hyangchal' and 'Gugyeol' writing used from Silla to Joseon seemed to emerge at the beginning of the Silla period. As a writing system, the Idu seemed to be established in the seventh century, because the script was used for public documents and official terminology through the Goryeo and Joseon Dynasties before the appearance of Hangeul. Of the existing documents written in Idu, Daemyeonglyul Jikhae, published in 1395, is known as the first translated text in Korea. Finally, the ancient writing systems such as Idu and its subgroups Hyangchal and Gugyeol made meaning and pronunciation so inefficiently difficult to parse that

\footnotetext{
${ }^{6}$ It is usually known that the original inventor of Idu was Seolchong, which is not easily acknowledged considering the fact that "Seodongyo" and "Hyeseongga" were composed in about the sixth century, and the Idu-written Namsan Sinseong Monument in Gyeongju was erected in 591 and Seolchong lived during the reign of King Shinmun (681-691).
} 
50 The Korean Tradition of Translation: From the Primeval Period to the Modern Era

they were gradually abandoned, to be replaced with Hangeul after the fifteenth century.

During the Goryeo Dynasty, as its exchange with other neighboring countries grew more active and foreign envoys came and went more frequently, Tongmungwan, a government office, was founded to take control of translation, interpretation and foreign language education. The institution established by recommendation of Kim Gu, an official Chammun-Haksa, in 1276 proposed both to correct interpretation carelessly carried out by poorly educated interpreters and to prohibit personal profiteering gained by intentional distorting of messages communicated. It picked out officials educated them in foreign languages such as Chinese, Georanese, Yeojinese, Mongolian, and Japanese. In the late Goryeo, more professional Sayeokwon replaced Tongmungwan, in order to be actively in charge of interpretation and translation, and continued to exist until the Joseon period.

\section{Simultaneous Use of Hanja and Hangeul: From the Promulgation of Hangeul to the Gap-o Reform}

At the beginning of the Joseon Dynasty, Sayeokwon maintained only Chinese Studies, yet within it, a Yeokhak (Translation Studies) program was soon set up, to which belonged additionally Mongolian and Japanese Studies. Moreover, as exchanges with neighboring foreign countries grew increasingly lively and the role of Yeokgwans $^{7}$ at government offices like Sayeokwon increased,

\footnotetext{
7 Officials who were in charge of translation, including interpreting, in the Goryeo and Joseon Dynasties and were also called 'Yeok-in,' 'Seol-in,' and 'Sang-seo.' Yeokgwans in the early days were usually appointed from the lower classes, but later men from the upper class with considerable knowledge learned this course of translation studies.
} 
foreign language education was encouraged more strongly than ever. Even at the beginning of the Joseon Dynasty, the Yeokgwa test appeared to select Yeokgwans. Its subjects were Chinese Studies, Mongolian Studies, Yeojin Studies (later Ching Studies), and Japanese Studies. ${ }^{8}$ Yeokgwans were usually in charge of interpreting in the field of foreign exchange with China, Monggol, Yeojin and Japan.

Interpreting both when domestic representatives were dispatched and when foreign envoys arrived, the Yeokgwans played an important role in the relationship of foreign exchange. They also gained a great deal of profit from secret trade through their frequent comings and goings to neighboring countries. So their contribution to the growth of foreign trade was great in the Joseon period. Yet they were always dissatisfied with being treated as ordinary men in spite of their noted intellect and economic powers as well as professional skills and administrative capabilities. In the late Joseon period, the Yeokgwans played more actively in order to free human status, and led the stream of Modernization. The representative figure who influenced the formation of the Enlightened School was Oh Kyung-seok. ${ }^{9}$

Although they had their own spoken language to express their feelings and thoughts even from the primeval period, the Koreans had no proper writing system to put those ideas on record. Chinese script was used only by the intelligentsia of the country and could not adequately encompass Korean spoken language. In a step to help

${ }^{8}$ In a code of laws in the early Joseon titled Gyeongguk-Daejeon (1485), there were 80 pupils prescribed in total; 35 in Chinese Studies, 10 in Monggolian Studies, 20 in Yeojin Studies, and 15 in Japanese Studies.

9 A famous Yeokgwan from middle class who frequently visited the Quing Dynasty and brought the books such as Haeguk-Doji and Youngwhan-Jiryak, let Hong-gi $\mathrm{Yu}$, one of his friends read them, and helped form the Enlightened School with the young politicians like Kim Ok-gyun, Park Young-hyo and Hong Young-sik. Especially interested in epigraphy, he selected lots of Chinese epigraphs, wrote well in seal characters, and was also excellent in painting. 
common people who were not able to read or to communicate their thoughts and feelings in written words, King Sejong immediately searched for solutions. What he was looking for was an alphabet that was exclusively Korean and easy to grasp, making it accessible and usable for laymen. In the end, Hangeul, the Korean script was first invented in 1443 and three years later was proclaimed in a document called Hunmin Jeong-eum, ${ }^{10}$ which recorded the creator's motivation and reason for making Hangeul:

Because the national language is different from that of China, it [spoken language] doesn't match [Chinese] letters. Therefore, when many common people want to communicate, most of them cannot achieve their intentions. Out of my sympathy for their difficulties, I have newly invented a set of 28 letters. ${ }^{11}$ It is my fervent hope that everybody learn the letters easily so that they can conveniently use them every day.

The King surely wanted to enable the Korean people to write their own language without using Chinese characters. The statement above implicitly expresses his dedication to national identity and cultural independence.

${ }^{10}$ Hunmin Jeong-eum (literally 'The Proper Sounds for the Instruction of the People') was an entirely new and native script for the Korean people. The script was initially named after the publication, and also known as Eonmun (vulgar script) and Gukmun (national writing). The modern name for the alphabet, Hangeul, was coined by a Korean linguist called Ju Si-gyeong (1876-1914). Kept in the Kansong Art Museum, the manuscript of the original Hunmin Jeongeum is South Korean National Treasure number 70 and has been a UNESCO Memory of the World Register since October 1997. The supposed publication date of the Hunmin Jeong-eum, October 9 (1446) became the Hangeul Day in South Korea. Its North Korean equivalent is on January 15.

11 Several Jamos (consonants and vowels) among 28 letters are today obsolete. These include four letters that represent Korean sounds that have since disappeared from the standard language; “ • $\overline{0} \Delta 0 . "$ 
King Sejong's idea of making common people literate was quite exceptional and reformative in the social atmosphere at that time, and it took a long time for the idea to be realized. First of all, the governing classes still maintained official literary lives using Chinese characters, and there were very slim chances for Hangeul to infiltrate them. Instead, Hangeul slowly began to expand its influence, playing a role set apart from Chinese characters. Since Hangeul was invented mainly for common people, it played an important role among them first. Although the number of Hangeulusers was steadily increasing among the governing classes, most men from the upper classes rarely used Hangeul unless in exceptional cases, veering instead towards official, privileged Chinese characters and Chinese writings.

After the Hangeul's promulgation, Hanja-written literatures were earnestly translated into Hangeul by scholars. In particular, 'Eonhae' is one of traditional terms for transforming Chinese characters of Hanja into other words of Hangeul. Of course, other transformation of languages other than Chinese into Hangeul has been still called 'translation.' The earliest works of Eonhae were Hunmin Jeong-eum Eonhae and Neungeomgyeong Eonhae. The first translated book of poems was Doosi Eonhae in which the entire poems of Doobo, a famous Chinese poet were divided into 52 sections and translated into Hangeul by $\mathrm{Yu}$ Yun-gyeom in 1482. For fifty years after Hunmin Jeong-eum was promulgated, translated literatures numbered 40 works, 200 books published.

Owing to the spread of Hangeul, the complications in expressing Korean language disappeared. Yet Chinese characters were still preferred by the upper classes, some of whom were interested in Hangeul only to express songs and Eonhae. Hangeul was seen as vulgar by the literate elite who preferred the traditional Hanja writing system. They gave it such coarse names as 'Eonmun' or 'Eongeul' (vulgar script), 'Amkeul' (women's script), and 
'Ahaekkeul' (children's script). ${ }^{12}$ On the other hand, Hangeul was also called 'Gagyageul' (Gagya writing), 'Gukseo' or 'Gukmun' (nation's script), 'Joseongeul' (Joseon's script), and 'Achimgeul' (writing you can learn within a morning).

Hangeul faced heavy opposition by the literate elite, such as Choe Man-ri and other Confucian scholars in the 1440s, who believed Hanja to be the only legitimate writing system. On the other hand, since common people had no choice, they gradually started to use Hangeul solely. Later rulers, however, became antagonistic to Hangeul. There was in fact an event which showed that not only common people but also increasing numbers of noble classes could read and write in Hangeul. A document in 1504 that criticizes the tyranny of King Yeonsangun was written in Hangeul. It seemed that the person who had written the document was a noble, and he intentionally used Hangeul in order to avoid exposure of his identity. In the same year, Yeonsangun forbade the study or use of Hangeul, banned Hangeul documents, and passed an order to report those who used the language. Later King Jeongjong abolished the Ministry of Eonmun in 1506.

Despite such incessant repression, Hangeul became increasingly popular. During the reign of King Sejo (1567-1608), Hangeul was widely spread among the populace, specifically of the lower status, i.e. women, children and the uneducated. In particular, women played an immense role in the expansion of its use. Although many noble women were taught Chinese writings, they gradually used Hangeul frequently. Especially, they used Hangeul when exchanging letters with other women or with men. Many books mostly for women were published strictly in Hangeul too.

The role of Buddhism should not be ignored in the spread of

${ }^{12}$ However, these names are now archaic, as the use of Hanja in writing has become very rare in South Korea and completely phased out in North Korea. Today, the name Urigeul / Urigŭl or "our script" is used in both North and South Korea in addition to Hangeul / Han'gŭl. 
Hangeul. Although the Joseon Dynasty formally took on the policy of respecting Confucianism and repressing Buddhism, the latter still kept an important position in the common people's hearts. The royals who were at the forefront of the invention and use of Hangeul, like King Sejong and Sejo, had a strong belief in Buddhism. Therefore, among many projects that could be done using Hangeul, they were enthusiastic in promoting the translation and publication of Buddhist scriptures. Although the vassals made strong protests against their attempts to build Buddhist temples at the palace in a bid to hold worship in front of Buddha and publish Buddhist scriptures, these projects continually lasted throughout the time of King Sejong, Munjong, and Sejo. Many Buddhist temples throughout the country went on publishing Buddhist scriptures afterward. The purpose was to let common people understand the nature of Buddhism and to achieve their religious goals by reading Buddhist scriptures written in Hangeul.

The sixteenth century saw a revival of Hangeul with the prosperity of 'gasa' literature, an old form of long verse and later 'sijo,' an old form of short verse. In the seventeenth century, Hangeul novels became a major genre. Particularly in the seventeenth and eighteenth centuries, novels contributed much in the diffusion of Hangeul. Many people in the governing classes indulged in Chinese novels at that time. They preferred love stories and popular novels to classic literature, and some noble people who read much of them used similar literary styles in their own writings as well. Despite King Jeongjo's infamous cultural policy of repression ('Munchei-banjeong'), these novels were translated in Hangeul and widely read by the common people too. Hangeul novels were distributed in the form of transcription at first, but later they were published in imprinted forms due to their commercial value. The fashionable nature of these novels and the rise of commercial publications were a sign of progress toward the modern times of Korea. Also, the switch over from the medieval culture 
emphasizing literary language to a modern culture valuing national language is evident here.

Hangeul as a writing system was established only at the end of nineteenth century. The Gap-o Reform of 1894, wherein reformers such as Kim Hong-jip expelled the corrupt reign of Princess Min and her party, helped modernize the political system of Korea. The positioning of Hangeul as a dominant character of Korea instead of Chinese characters meant progress toward the modern era. The assertion that Korea could become a modern and powerful country only if the people used Hangeul instead of Chinese characters had great force. Even though it took a long time, what King Sejong had in mind when he invented Hangeul eventually came true. Due to the growth of Korean nationalism in the nineteenth century, Japan's attempt to sever Korea from China's sphere of influence, and the Gap-o Reformists' push, Hangeul was eventually adopted in official documents for the first time in 1894. Elementary school texts began using Hangeul in 1895, and the Dongnip Sinmun, established in 1896, was one of the first newspapers printed exclusively in Hangeul.

The translation into Hangeul generally began to flourish at the beginning of the modern era, the end of nineteenth century. Yet before the great Reform of 1894, there were frequently Hangeultranslated versions, a majority of which consisted of religious documents like the Bible as in the most Western countries. As translations of the Bible were necessary for the spread of Christianity in Europe, the translation of the Bible in Korea was done in the same context. In 1885, Lee Soo-jeong published a Korean version of the Bible, Eonhae of Marco's Gospel, the New Testament. There had been, of course, several versions of the Bible in Korean before this version, but this was the first translated by a Korean. In fact, what Korean versions of the Bible contributed much to the translation history of Korea was, as professor Byung-cheol Kim emphasizes, "the resolute acceleration of unification between 
the written and spoken language, eradicating a deformed usage of language which is usually spoken in Korean and written in Chinese for a long time" (18).

\section{Future Prospects for Translation in Korea}

These days, the world is rapidly becoming a global village, with epoch-making developments of transportation and correspondence, the daily use of the Internet, and the borders between nations increasingly vague. The world is rapidly transforming from a conventional trade-market to a marketplace of direct transaction. In our globalized world, a language is not only a communication method but also a cultural heritage containing a nation's history and spirit. The nation that once loses its original language cannot be called a nation any more. For example, it is not farfetched to say that Manchuria tribes disappeared after losing Manchu. Korea was also faced with the crisis of losing its language under the rule of Japanese imperialism, but the Koreans succeeded in maintaining their nation's identity by keeping their original language and writings. Opening their mind to foreigners and foreign languages, the Korean people seek to keep pace with the stream of the world's change by paying attention to foreign languages and foreign cultures as well as succeeding and developing their language and writings. That is the acumen necessary to live in this globalized world.

We have been living in a world of manifold languages. ${ }^{13}$ In

${ }^{13}$ How many languages exist on our planet? The website of UNESCO declares, "For different linguistic, social and historical reasons, there is no single answer to this question," and then adds: "A first reason for the uncertainty over numbers is that even today new peoples-and with them their languages-are 'discovered,' especially in the Amazonas region, Central Africa and New Guinea. However, only few languages are discovered like this. It is much more difficult to estimate the actual linguistic variety in areas where people are known, be it because of missing or incomplete linguistic surveys or confusion with a local dialect" 
other words, we live in a world of translation. That the role of translation in cultural exchange is tremendous has been proved in the history of Korea. The dynamics of translation through the Korean history of translation reminds us of Mona Baker's warning that "One of the most fascinating things about exploring the history of translation is that it reveals how narrow and restrictive we have been defining our object of study, even with the most flexible of definitions" (xvii). In Korea, translation necessarily has concerned the field of import/export of culture as well as goods. In particular, as the world suddenly and gradually becomes a small global village nowadays, the interest in translation is recently increased in Korea higher than in any other time or place.

In Korea today, one can find without difficulty various signs of unequaled interest in translation. The fact that a large number of translated books are published surely affirms that Korea is a testament to the unsurpassed value of translation in Korea. A lot of translation-related professional societies such as the Korean Association of Translation Studies are currently established, publishing translation journals. As a dozen of universities open translation-related programs, a number of $\mathrm{MA} / \mathrm{PhD}$ dissertations have followed. For the last twenty years, an incredible number of texts concerned with translation theory are written and translated in succession.

Korea continues to develop the momentum to continuously internationalize its culture under the slogan of 'globalization' adequate to the current of the contemporary world. Here is the role

$<$ http://portal.unesco.org/ci/en/ev.php-URL_ID=11173\&URL_DO=DO_TOPIC\&URL_ SECTION $=201 . h t m l>$. Although it is impossible to accurately say how many languages are spoken in the world, a noted linguist, H.F. Wendt maintained, "The number of languages on the planet is more than 2500" (355). According to K. Katzner, the number of languages may be several thousands (Chapter VIII). Hee-seong Kang emphasizes that the Bible was already translated into 1631 languages (Kang 24). 
of translation specifically required. The effect of translation upon cultural exchanges, international tourism and the improvement of trade cannot be overstated. The acceptance of foreign culture and the transference of domestic traditional culture are what the Korean people must continue to do. The man who plays a vanguard in the field of international cultural exchange must be an expert and skilled translator. The translation field in Korea nevertheless is in many ways in shambles. Although they agree with the importance and necessity of translators, most Koreans do not usually look so favorably on the status of a translator. There are no institutes to nurture competent translators at the dimension of nation and society. Therefore, the finding and upbringing of expert translators who will actively part in the historical task to create a global culture are an urgent affair.

Fortunately enough, there are innumerable would-be translators and dozens of professional institutes for educating them in Korea. Yet the ineffectual education of translators may produce quite contrary results in the field of cultural exchange. In Korea, as the number of the Internet users has enormously grown in these days, life patterns in various areas are rapidly and immensely changing and the exchange with other nations is rapidly developing according to the waves of globalization. Therefore, it is time to put an end to translational training focused only and strictly on transforming literal letters. Adapting the purpose and content of translational education to the Internet age is a prerequisite. A concrete plan along with positive investment for fostering competent translators as a part of kernel enterprises at the national level is necessarily and urgently drawn up. 
60 The Korean Tradition of Translation: From the Primeval Period to the Modern Era

\section{References}

Baker, M. 1998. Routledge Encyclopedia of Translation Studies. London \& New York: Routledge.

Bassnett, S. 1993. Comparative Literature: A Critical Introduction. Oxford \& Cambridge: Blackwell Publishers.

. 1991. Translation Studies. London \& New York: Routledge.

Bell, R. 1991. Translation and Translating: Theory and Practice. London \& New York: Routledge.

Benjamin, W. 1968. Illumination. In H. Arendt (ed.). \& Trans. H. Zohn. NY: Schocken Books.

de Lotbinière-Harwood, S. 1991. The Body Bilingual: Translation as a Rewriting in the Feminine. Montreal \& Toronto: Les éditions du Remue-ménage.

Evan-Zohar, I. Translation Theory Today. Poetics Today 2.4, 1-7.

Hatim, B. \& I. Mason. 1997. The Translator as Communicator. London \& New York: Longman

Hervey, S. \& I. Higgins. 1992. Thinking Translation: A Course in

Translation Method: French to English. London \& New York:

Routledge.

Kang, H. A Stream of Contemporary Translational Theories. Literary Criticism Today (Winter 1995), 22-34.

Katzner, K. 1975. The Language of the World. London \& New York: Routledge.

Kim, B. 1988. A Sdudy on Translational History of Modern Era in Korea. Seoul: Eul-U Culture Publishing.

Lefevere, A. 1992. Translating Literature: Practice and Theory in a Comparative Literature Context. NY: The Modern Language Association.

Simon, S. 1996. Gender in Translation: Cultural Identity and the Politics of Transmission. London \& New York: Routledge. Wendt, H.F. 1977. Sprachen. Frankfurt: Fischer Bücherei. 